\title{
Evaluation of some residual bioactivities of microencapsulated Phaseolus lunatus protein fraction with carboxymethylated flamboyant (Delonix regia) gum/sodium alginate
}

\author{
Mukthar SANDOVAL-PERAZA ${ }^{1}$, David BETANCUR-ANCONA ${ }^{1}$, \\ Santiago GALLEGOS-TINTORÉ ${ }^{1}$, Luis CHEL-GUERRERO ${ }^{1 *}$
}

\begin{abstract}
Recent studies have shown the beneficial effect of peptides, an unexploited source could be Phaseolus lunatus being an important raw material for those functional products in order to improve their utilization. In addition to improve the beneficial effect of bioactive peptides the microencapsulation could be a way to protect the peptides against the environment to which they are exposed. $P$. lunatus protein fraction ( $<10 \mathrm{kDa}$ of weight) was encapsulated using a blend of carboxymethylated flamboyant gum (CFG) and sodium alginate (SA) at different concentrations of $\mathrm{CaCl}_{2}$ and hardening times. After in vitro digestion of microcapsules the residual activity, in the intestinal system, both inhibition of agiotensin-converting enzyme (I-ACE) and antioxidant activity obtained were in a range of $0.019-0.136 \mathrm{mg} / \mathrm{mL}$ and $570.64-813.54 \mathrm{mM}$ of TEAC respectively. The microencapsulation employed CFG/SA blends could be used controlled delivery of peptide fractions with potential use as a nutraceutical or therapeutic agents.
\end{abstract}

Keywords: microencapsulation; flamboyant gum; antioxidant activity; ACE-I activity.

\section{Introduction}

Phaseolus lunatus is one of the most representative in the tropical zone of Mexico and is an unexploited protein source (Betancur-Ancona et al., 2009). Chel-Guerrero et al. (2002) reported an adequate quantity and quality in isoelectric protein isolates from $P$. lunatus but with some limited functional properties. Protein hydrolysis by enzymatic proteins is an effective way of modifying functional properties that depends on the ratio of enzyme to substrate, hydrolysis time and temperature which changes its degree of hydrolysis (DH). After protein hydrolysis some peptides (2-15 amino acid sequences) with physiological effect can be released (Vioque et al., 2006). Several research report relevant bioactive properties in many peptides extracted from plants and animal origin. These peptides exhibit diverse biological activities including antioxidant, antithrombotic, antibacterial, antifungal, blood pressurelowering (ACE inhibition), cholesterol-lowering ability, anticariogenic, etc. (Iwaniak \& Minkiewicz, 2007; Hartmann \& Meisel, 2007). Angiotensin-I converting enzyme (ACE-I) is a $\mathrm{Zn}$-metal-peptidase synthesized in the lung. Inhibition of the renin-angiotensin system (RAS) by administration of an angiotensin-converting enzyme (ACE) inhibitor reduces the blood pressure in the human body (Sica, 2007). Free radicals and other reactive species can cause oxidation and biomolecular damage when the oxidative species exceed the anti-oxidative defenses of the organism resulting in oxidative stress. These reactions are implicated in the etiology of many multifactorial degenerative diseases such as cancer, cardiovascular disease, neurodegenerative disorders, diabetes, etc. (Torruco-Uco et al., 2009; Rodrigues et al., 2011). To guaranty the activity of these bioactive peptides, it must remain active and intact during the gastrointestinal digestion and absorption in order to achieve their physiological effects. But once it is in the organism all peptides go through different barriers that can inactivate them and consequently lose their efficiency (Segura-Campos et al., 2011).

Microencapsulation protects nutraceuticals, keeping them stable stored at room temperature and ensures the release of an appropriate dosage at a gastric or intestinal $\mathrm{pH}$. The use of modified polysaccharides with ionic charges to encapsulate substances with biological activity has become increasingly popular in the nutraceutical food and pharmaceutical industries (Andreev, 2004). Flamboyant tree (Delonix regia) is a legume plant widely grown in tropical and sub-tropical regions. The few branched regions present in its native gum consist of $a-D$ mannose $(1 \rightarrow 4)$ linkages and $\alpha$-D-galactose $(1 \rightarrow 6)$ branches in a 4:1 ratio of mannose-galactose (Tamaki et al., 2010). Its structure is similar to those of guar gum, but differs in terms of the $\mathrm{OH}$ bond position in the main chain: flamboyant gum has $\alpha$-D-mannose while guar gum has $\beta$-D-mannose (Kapoor, 1972). Betancur-Ancona et al. (2011) mentioned the use of modified polysaccharides like carboxymethylcelullose, carboxymethylated guar gum and carboximethylated starch in the encapsulation of nutraceuticals substances. These authors report the microencapsulation of papain using carboxymethylated flamboyant seed gum as a model of bioactive release molecules. The objective of this research was to evaluate the residual activity of the Phaseolus lunatus peptidic fraction $(<10 \mathrm{kDa})$ microencapsulated with carboxymethylated flamboyant and chia gums. 


\section{Materials and methods}

\subsection{Seeds and chemicals}

Delonix regia seed pods were collected in Yucatan, Mexico. A total of $5 \mathrm{~kg}$ of seeds were collected and stored in polyethylene bags at $4^{\circ} \mathrm{C}$ until use. Phaseolus lunatus seeds were obtained from harvest 2013 in the state of Yucatan, Mexico. Reagents were analytical grade and purchased from J.T. Baker (Phillipsburg, NJ, US), SIGMA (Sigma Chemical Co., St. Louis, MO, US), Merck (Darmstadt, Germany) or Bio-Rad (Bio-Rad Laboratories, Inc. Hercules, CA, US).

\subsection{Delonix regia gum extraction and carboxymethylation}

Flamboyant native gum (FNG) was obtained from seed endosperm following Betancur-Ancona et al. (2011) with some modifications. After endosperm extraction a water suspension (3:1 v/w) was prepared and blended to obtain a homogenous dispersion. This dispersion was heated at $60^{\circ} \mathrm{C}$ under constant agitation for $30 \mathrm{~min}$. It was then filtered sequentially through a mesh to separate the fibrous particles from the gum. The FNG was precipitated with ethanol at $95 \%$ with a $3: 1 \mathrm{v} / \mathrm{v}$ proportion and dried at $60^{\circ} \mathrm{C}$ for $24 \mathrm{~h}$ in a circulating air oven (Imperial V Lab-Line Model 3476 M, Boston US). The FNG was modified by carboxymethylation using sodium chloroacetate (SCA) under heterogeneous conditions following Bahamdan \& Daly (2006). The degree of substitution (DS) in CFG was determined by titration with $\mathrm{HCl} 0.5 \mathrm{~N}$.

\subsection{Flour production and protein concentrate (PC)}

The Phaseolus lunatus seeds were cleaned and grounded in a Mycros impact mill and then ground in a Cyclotec 1093 (Tecator, Sweden) mill until passing through a $60(246 \mu \mathrm{m})$ mesh. The PC was obtained by precipitation of the protein at the isoelectric point (4.5) according Betancur-Ancona et al. (2004).

\subsection{Proximate composition for FNG and PC from Phaseolus lunatus}

The Association of Official Analytical Chemists (1990) methods were used to determine nitrogen (method 954.01), fat (920.39), ash (923.03), fiber (962.09) and moisture (925.09) content of the FNG and CP. Protein content was calculated as nitrogen 6.25 , and carbohydrate content was estimated as nitrogen-free extract (NFE).

\subsection{Enzymatic hydrolysis}

Protein hydrolysis was performed according to ChelGuerrero et al. (2012), with a sequential pepsin-pancreatin system. The degree of hydrolysis $(\mathrm{DH})$ was calculated by ratio between free amino groups, through reaction with o-phthaldialdehyde (OPA) reagent (Nielsen et al., 2001) using a serine standard and total number of amino groups determined in a $100 \%$ hydrolized sample by treatment with $6 \mathrm{~N} \mathrm{HCl}$ at $110^{\circ} \mathrm{C}$ for $24 \mathrm{~h}$ in a vacuum oven. This analysis was repeated twice.

\subsection{Sodium dodecyl sulphate-polyacrylamide gel electrophoresis (SDS-PAGE)}

The SDS-PAGE analysis was done following Schägger \& Von Jagow (1987). Runs were carried out with 13\% and 18\% acrylamide gels to $\mathrm{PC}$ and protein hydrolysate $(\mathrm{PH})$ samples, respectively.

\subsection{Ultrafiltration of Protein Hydrolysate}

The ultrafiltration was done following Cho et al. (2004). A fraction with a molecular mass of $<10 \mathrm{kDa}$ was obtaining by ultrafiltration, using ultrafiltration membranes (Millipore PLGC06210, Bedford, MA, US).

\subsection{Microencapsulation}

CFG/SA microcapsules were prepared based on Sankalia et al. (2004). A $2^{3}$ Factorial design with 4 central treatments was used (Table 1), response factors were the amount of protein released and their residual bioactivity. 1.5 $\mathrm{g}$ of blend CFG/SA were dispersed in $150 \mathrm{~mL}$ distilled water at the concentrations established in the experimental design and $600 \mathrm{mg}$ of protein (<10 $\mathrm{kDa}$ fraction) was added. Once dispersed, all solution was passed through a peristaltic pump (Cole-Palmer, Model 7553-70, Barrington, US) with a 2 mm ID Masterflex $^{\circledR}$ hose at $0.17 \mathrm{~mL} / \mathrm{s}$. As drops exited the hose they

Table 1. Microencapsulation efficiency and flow capacity in the peptide fraction encapsulated with CFG/SA.

\begin{tabular}{|c|c|c|c|c|c|c|}
\hline \multirow{2}{*}{ Treatment $(\mathrm{T})$} & \multicolumn{3}{|c|}{ Factors ${ }^{\star}$} & \multirow{2}{*}{$\begin{array}{c}\text { Microencapsulation } \\
\text { efficiency }(\%)\end{array}$} & \multirow{2}{*}{ Angle of repose } & \multirow{2}{*}{ Flow Capacity } \\
\hline & $\mathrm{A}(\mathrm{CFG} / \mathrm{SA})$ & $\mathrm{B}(\mathrm{M})$ & $\mathrm{C}(\mathrm{min})$ & & & \\
\hline 1 & $70: 30$ & 0.05 & 20 & $\mathrm{NF}$ & ND & ND \\
\hline 2 & $30: 70$ & 0.05 & 20 & $34.77^{\mathrm{a}}$ & $28.82^{a} \pm 0.8$ & Excellent \\
\hline 3 & $70: 30$ & 0.15 & 20 & NF & ND & ND \\
\hline 4 & $70: 30$ & 0.05 & 30 & NF & ND & $\mathrm{ND}$ \\
\hline 5 & $30: 70$ & 0.15 & 20 & $33.51^{\mathrm{a}}$ & $34.65^{c} \pm 1.5$ & Good \\
\hline 6 & $30: 70$ & 0.05 & 30 & $36.27^{\mathrm{a}}$ & $29.47^{\mathrm{a}} \pm 1.3$ & Excellent \\
\hline 7 & $70: 30$ & 0.15 & 30 & NF & ND & ND \\
\hline 8 & $30: 70$ & 0.15 & 30 & $31.49^{\mathrm{a}}$ & $33.99^{c} \pm 4.5$ & Good \\
\hline $9-12(\mathrm{CT})$ & $50: 50$ & 0.1 & 25 & $33.43^{\mathrm{a}}$ & $32.2^{\mathrm{b}} \pm 0.3$ & Good \\
\hline Blank & $0: 100$ & 0.15 & 30 & $24.11^{\mathrm{a}}$ & $33.6^{c} \pm 1.52$ & Good \\
\hline
\end{tabular}

${ }^{*}$ A: Gum ratio (CFG/SA); B: $\mathrm{CaCl}_{2}$ concentration; C: Hardening. CT: central treatments; ${ }^{\dagger}$ Flow capacity according to Swarbrick (1997) scale; NF: not form; ND: not determined; Different superscript letters in column indicate statistical difference $(\mathrm{P}<0.05)$. 
fell a distance of $10 \mathrm{~cm}$ into $250 \mathrm{~mL}$ of $\mathrm{CaCl}_{2}$ solution to form microcapsules and were left to harden in the cationic solution for the time set in the experimental design. Microcapsules were recovered by decanting the solution, then washed with deionized water and freeze-dried at $-47^{\circ} \mathrm{C}$ and $13 \times 10^{-3} \mathrm{mbar}$. In addition, an alginate blank was prepared at 0.15 of $\mathrm{CaCl}_{2}$ concentration and $30 \mathrm{~min}$ of hardening time under the same treatment tests.

\subsection{Particle size and morphology}

Particle size (PS) was measured with a Vernier instrument. The particle morphology was recorded for five microcapsules per treatment with an Stereo Microscope (5x, MOTIC microscopies SMZ-168, Richmond BC, Canada) with camera of 10 mega pixels, using the Motic Images Manager (v. Plus 2.0) image program.

\subsection{Microcapsule flow capacity}

Following Swarbrick (1997), microcapsule flow capacity (FC) was calculated by measuring angle of repose, which simulates protection of the active ingredient in the intestinal tract. The microcapsules were passed though a funnel $(12 \mathrm{~mm}$ internal diameter, $70 \mathrm{~mm}$ long) at a height of $10 \mathrm{~cm}$ on a horizontal surface to form a pile. Pile height $(\mathrm{h})$ and cone base radius $(r)$ were measured with a Vernier, and angle repose $(\varphi)$ was calculated with the Equation 1 (Sankalia et al., 2004).

$\varphi=\tan ^{-1} \frac{h}{r}$

\subsection{In vitro release studies}

For each treatment, microcapsule in vitro release capacity was evaluated with an adapted version of the method of Takagi et al. (2003). Briefly, $100 \mathrm{mg}$ of dry capsules were placed into $50 \mathrm{~mL}$ beakers, and then $25 \mathrm{~mL}$ of $\mathrm{HCl}$ solution at $\mathrm{pH} 2$ with $2 \mathrm{mg} / \mathrm{mL}$ of $\mathrm{NaCl}$ was added. This mixture was homogenized with a stir-pak (Cole-Parmer 50002-30, Vernon Hills IL, US) at $350 \mathrm{rpm}$ for $2 \mathrm{~h}$ at $37^{\circ} \mathrm{C}$, to simulate the gastric system (GS). The microcapsules were recovered by decanting the solution and placed into $50 \mathrm{~mL}$ beakers, and then $25 \mathrm{~mL}$ of $0.25 \mathrm{M}$ phosphate buffer at $\mathrm{pH} 6.8$ was added. This mixture was mixed with a stir-pak (Cole-Parmer 50002-30, Vernon Hills IL, US) at $500 \mathrm{rpm}$ for $3 \mathrm{~h}$ at $37^{\circ} \mathrm{C}$, to simulate the intestinal system (IS). The content of protein released in GS and IS was quantified according to Lowry et al. (1951).

\subsection{Antioxidant activity}

The ABTS decolorization assay was done as described by Pukalskas et al. (2002). The antioxidant activity in the samples was quantified by mixing $10 \mu \mathrm{L}$ from GS and IS aliquots and $990 \mu \mathrm{L} \mathrm{ABTS}^{+}$radical cation and measuring absorbance at $734 \mathrm{~nm}$ after $6 \mathrm{~min}$.

\subsection{ACE inhibitory activity}

ACE was prepared according to Hayakari et al. (1978) Rabbit lungs were used as starting material and the aliquots obtained were stored at $-20^{\circ} \mathrm{C}$ for no more of two months.
ACE inhibition from GS and IS aliquots, was evaluated in $20 \mu \mathrm{L}$ of solution from these samples. Determination of $\mathrm{IC}_{50}$ was performed by plotting log concentration of GS and IS protein $(\mathrm{mg} / \mathrm{mL})$ vs. percentage of ACE-I activity.

\subsection{Amino acids composition}

After intestinal digestion protein amino acid composition was determined in the remnant protein in IS, following the method of Alaiz et al. (1992). Amino acids were separated using HPLC with a reversed-phase column $(300 \times 3.9 \mathrm{~mm}$, Nova Pack $\mathrm{C}_{18}, 4 \mu \mathrm{m}$; Waters). Tryptophan was determined according Yust et al. (2004).

\subsection{Statistical analysis}

All results were analyzed using descriptive statistics with central tendency and dispersion measures. A factorial $2^{3}$ statistical analysis was carried out and regression analysis for the determination of statistical significance of the factors. The independent variables were: gum ratio $(\mathrm{A}), \mathrm{CaCl}_{2}$ concentration (B) and hardening time (C). All analyses were done according to Montgomery (2001) and processed with the Statgraphics Plus version 5.1 software.

\section{Results and discussion}

\subsection{Proximate composition for FNG and P. lunatus PC}

FNG had a high content of NFE (97.82\%) this amount is considered as the polysaccharide content. Regard to the degree of substitution under conditions of $10 \%$ of $\mathrm{NaOH}, 10 \%$ of CAS and $90 \mathrm{~min}$ of reaction a value of 0.4639 was obtained. PachecoAguirre et al. (2010) reported a DS value of 0.33 under conditions of $40 \% \mathrm{NaOH}, 40 \%$ CAS and time $180 \mathrm{~min}$. The differences in the above values may be due to the conditions used. For example, the role of the solvent in the caboxymethylation is to provide accessibility to the esterifying agent to react with the chains of mannose-galactose flamboyant gum. The concentration and time reaction also produces alkali competing reactions reducing the degree of substitution. Likewise higher temperatures favor diffusion of reactants by increasing solubility (Zhao et al., 2003).

The protein content in PC of Phaseolus lunatus were $70.36 \%$. This value is similar to the reported by Polanco-Lugo et al. (2014) with a $72.01 \%$ obtained from the same type of seed. Moreover, Chau et al. (1997) report the content of the protein concentrate of Phaseolus angularis (79.36\%) and Phaseolus calcaratus (78\%) which were higher. The PC obtained in P. lunatus in this study contain enough protein for its use in an enzymatic hydrolysis for the production of bioactive peptides.

\subsection{Electrophoresis (SDS-PAGE), DH and ultrafiltration}

PC showed bands with high molecular weights (Figure 1) in a range of $94.15-16.27 \mathrm{kDa}$. In the case of protein hydrolysate $(\mathrm{PH})$ showed bands with a lower molecular weight, highlighting the $10,6.8$ and $5.26 \mathrm{kDa}$. Yust et al. (2003) report the presence of peptides with molecular weights in the range of 17-6.2 kDa, in the hydrolysed of legumin, the main protein present in chickpea, these peptides exhibited ACE-I inhibitory activity. 

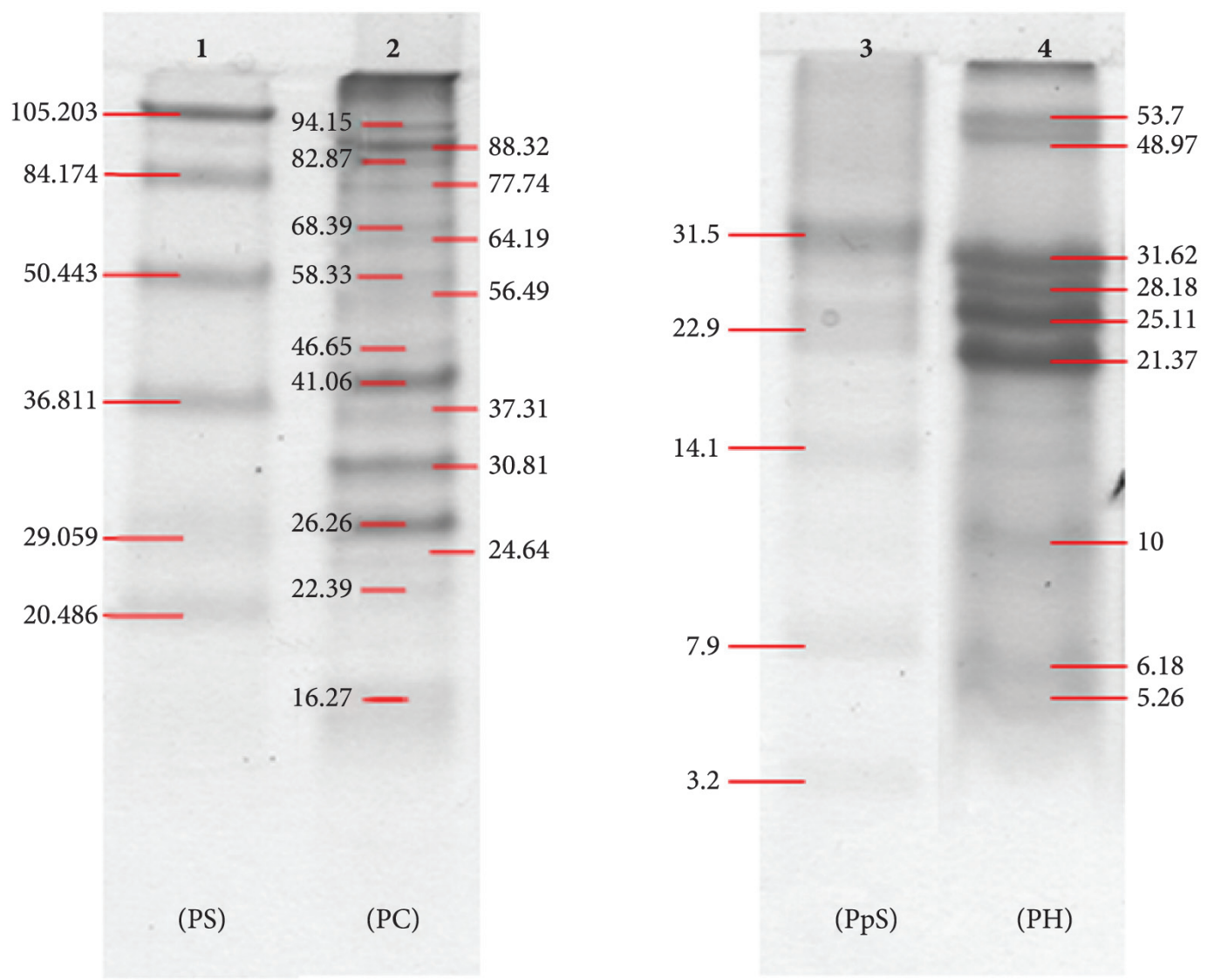

Figure 1. Electrophoretic profiles of protein concentrate (PC) and protein hydrolysate (PH) from Phaseolus lunatus. (PS: Protein standard; PpS: peptide standard).

DH in the PC in Phaseolus lunatus with pepsi-pancreatin sequential system was $25.12 \%$. Chel-Guerrero et al. (2012) reported DH values between $15.35 \%$ and $37.07 \%$ with pepsinpancreatin enzyme system at different reactions times, showing that the value obtained is within the range reported, where the difference in the percentage of hydrolysis may be caused by the time reaction of the enzyme towards the substrate. Vioque et al. (2006) noted that obtaining a DH below $10 \%$ improves the functional properties of a protein concentrate. Values above $10 \%$ allow the production of bioactive peptides. With ultrafiltration a peptide fraction was obtained $(<10 \mathrm{kDa})$ with a protein content of $49.48 \%$ with an initial activity of ACE and antioxidant activity of $0.37 \mathrm{mg} / \mathrm{mL}\left(\mathrm{IC}_{50}\right)$ and $26.94 \mathrm{mM}$ of TEAC protein, respectively.

\subsection{Microencapsulation}

Treatments 1, 3, 4, and 7 did not form capsules, observing that factor A (gum ratio) was significant. Due to the above, the treatments that did form capsules and the alginate blank were evaluated through a simple ANOVA analysis, and the differences among averages were determined through a Tukey test. Similar behavior was reported by Betancur-Ancona et al. (2011) when encapsulating CFG papain only, noting that a lower concentration of gum capsules were not formed.

\subsection{Microencapsulation efficiency, flow capacity and morphology}

Table 1 show the values of encapsulation efficiency where values were in the range of 24.11 to $36.27 \%$ and there were no significant differences ( $p>0.05)$. These values compared with those reported by Ruiz-Ruiz et al. (2013) which obtained values of encapsulation efficiency of 51.8 to $71.8 \%$ for $P$. lunatus hydrolysates. The high values of these authors compared with this work may be due to the encapsulated material which was a hydrolysate as compared to the peptide fraction of this study. Additionally, the authors above mentioned examined the effect of $\mathrm{pH}$ on encapsulation, noting that the increase of this factor enhance encapsulation. Regarding the flow capacity, a good value of flow was obtained according to the scale cited by Swarbrick (1997); this is desirable because it allows to predict the behavior of the microcapsule in the gastrointestinal tract (Swarbrick, 1997). Xu et al. (2007) reported a similar value of flow for microcapsules formed with modified starch (35.3) which is similar compared to this work.

The morphology and particle size is shown in Figure 2. In this case, the statistical analysis showed that there were no significant differences $(\mathrm{p}>0.05)$ relative to the size of the capsules between treatments. 


\subsection{Protein released}

The released amounts of peptide fraction in relation with the initial protein content in gastric and intestinal systems are shown in the Table 2. The statistical analysis showed significant differences $(\mathrm{p}<0.05)$ for both gastric and intestinal medium. The aim of the encapsulation is to protect the peptide in order for it to reach intact the intestine and enabling its beneficent action. Taking into account this fact the best treatment would be 8 because it is the one that retained more protein inside after the gastric digestion.
If the alginate blank is compared against treatment 8 , it can be observed that the combination of gums permitted to retain protein in gastric medium and released in the intestinal medium. The encapsulation by ionic gelation has been widely used in the encapsulation of cells; it has recently attracted attention for use as a means of release of protein; however, it does not control the release of proteins for prolonged periods (Yeo et al., 2001). This may be an explanation for the capsules formed with CFG:SA as well as those with only SA did not have the ability to retain protein. Another explanation to the release
70:30 (CFG:SA)

50:50 (CFG:SA)

30:70 (CFG:SA)

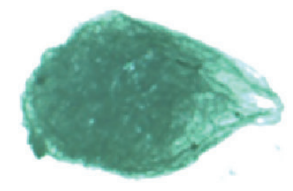
D: $1.38 \mathrm{~mm}$

$0: 100$

(GCMF:SA)
Blank $^{\mathrm{b}}$

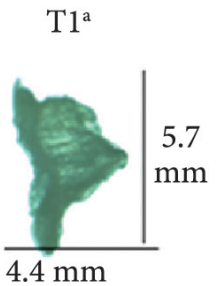

D: $2.76 \mathrm{~mm}$

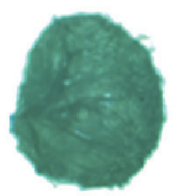

$\mathrm{T} 2^{\mathrm{b}}$

D: $2.53 \mathrm{~mm}$

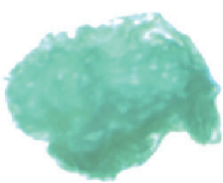

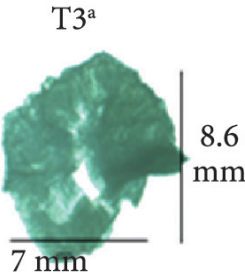
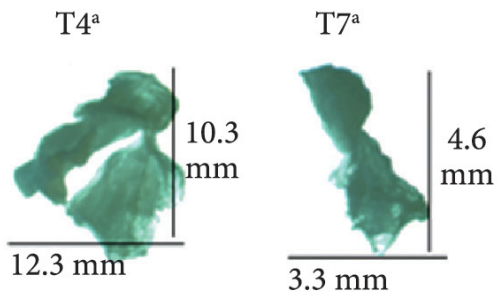

D: $2.21 \mathrm{~mm}$

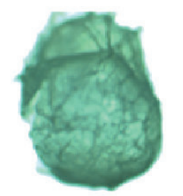

$\mathrm{T}^{\mathrm{b}}$

D: $1.32 \mathrm{~mm}$

D: $2.19 \mathrm{~mm}$

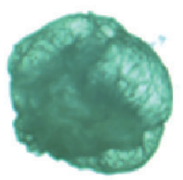

D: $2.08 \mathrm{~mm}$

$\mathrm{T} 5^{\mathrm{b}}$

D: $1.64 \mathrm{~mm}$

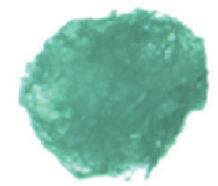

$\mathrm{T} 8^{\mathrm{b}}$

D: $1.28 \mathrm{~mm}$
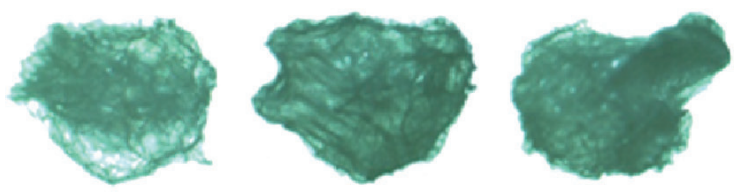

Figure 2. Microcapsules morphology and particle size. Different superscript letters in column indicate statistical difference $(\mathrm{P}<0.05)$.

Table 2. Released protein in gastric and intestinal systems.

\begin{tabular}{|c|c|c|c|c|c|}
\hline \multirow{2}{*}{ Treatment $(\mathrm{T})$} & \multicolumn{3}{|c|}{ Factors ${ }^{\star}$} & \multirow{2}{*}{$\begin{array}{c}\text { GS Protein released } \\
(\%) \dagger\end{array}$} & \multirow{2}{*}{$\begin{array}{l}\text { IS Protein releasec } \\
\qquad(\%) \dagger\end{array}$} \\
\hline & A (CFG/SA) & $\mathrm{B}(\mathrm{M})$ & $\mathrm{C}(\mathrm{min})$ & & \\
\hline 1 & $70: 30$ & 0.05 & 20 & ND & ND \\
\hline 2 & $30: 70$ & 0.05 & 20 & $78.63^{\mathrm{e}}$ & $3.42^{\mathrm{b}}$ \\
\hline 3 & $70: 30$ & 0.15 & 20 & ND & ND \\
\hline 4 & $70: 30$ & 0.05 & 30 & ND & ND \\
\hline 5 & $30: 70$ & 0.15 & 20 & $80.24^{\mathrm{f}}$ & $3.55^{\mathrm{c}}$ \\
\hline 6 & $30: 70$ & 0.05 & 30 & $78.35^{\mathrm{d}}$ & $3.11^{\mathrm{e}}$ \\
\hline 7 & $70: 30$ & 0.15 & 30 & ND & ND \\
\hline 8 & $30: 70$ & 0.15 & 30 & $70.75^{\mathrm{b}}$ & $25.62^{\mathrm{a}}$ \\
\hline $9-12(\mathrm{CT})$ & $50: 50$ & 0.1 & 25 & $72.33^{c}$ & $5.95^{\mathrm{d}}$ \\
\hline Blank & $0: 100$ & 0.15 & 30 & $68.02^{\mathrm{a}}$ & $0^{\mathrm{f}}$ \\
\hline
\end{tabular}

${ }^{*} \mathrm{~A}$ : Gum ratio (CFG/SA); B: $\mathrm{CaCl}_{2}$ concentration; C: Hardening; CT: central treatments; ${ }^{\dagger}$ Percentage of protein released in relation with the initial protein content (Table 1); ND: not determined; Different superscript letters in column indicate statistical difference $(\mathrm{P}<0.05)$. 
Table 3. Residual antioxidant and ACE activities from PH fraction released in gastric and intestinal systems.

\begin{tabular}{|c|c|c|c|c|c|c|c|}
\hline \multirow{2}{*}{ Treatment $(\mathrm{T})$} & \multicolumn{3}{|c|}{ Factors $^{*}$} & \multicolumn{2}{|c|}{ TEAC $(\mathrm{mM})$} & \multicolumn{2}{|c|}{$\operatorname{ACE}\left(\mathrm{IC}_{50} \mathrm{mg} / \mathrm{mL}\right)$} \\
\hline & $\mathrm{A}(\mathrm{CFG} / \mathrm{SA})$ & $\mathrm{B}(\mathrm{M})$ & $\mathrm{C}(\mathrm{min})$ & GS & IS & GS & IS \\
\hline 1 & $70: 30$ & 0.05 & 20 & ND & ND & ND & ND \\
\hline 2 & $30: 70$ & 0.05 & 20 & $2268.95^{\mathrm{e}}$ & $673.10^{\mathrm{b}}$ & $0.457^{c}$ & $0.02^{\mathrm{a}}$ \\
\hline 4 & $70: 30$ & 0.05 & 30 & ND & ND & ND & ND \\
\hline 5 & $30: 70$ & 0.15 & 20 & $2220.30^{\mathrm{d}}$ & $570.64^{\mathrm{e}}$ & $0.40^{\mathrm{bc}}$ & $0.02^{\mathrm{a}}$ \\
\hline 8 & $30: 70$ & 0.15 & 30 & $1942.86^{\mathrm{c}}$ & $813.54^{\mathrm{a}}$ & $0.333^{\mathrm{ab}}$ & $0.136^{\mathrm{c}}$ \\
\hline $9-12(\mathrm{CT})$ & $50: 50$ & 0.1 & 25 & $1928.27^{\mathrm{b}}$ & $615.10^{\mathrm{d}}$ & $0.356^{\mathrm{b}}$ & $0.035^{\mathrm{b}}$ \\
\hline Blank & $0: 100$ & 0.15 & 30 & $853.02^{\mathrm{a}}$ & $0^{\mathrm{f}}$ & $0.24^{\mathrm{a}}$ & ND \\
\hline
\end{tabular}

${ }^{\star} \mathrm{A}$ : Gum ratio (CFG/SA); B: $\mathrm{CaCl}_{2}$ concentration; C: Hardening; CT: central treatments; ND: not determined; Different superscript letters in column indicate statistical difference (P < 0.05).

Table 4. Amino acid composition in treatment 8 (g/100 $\mathrm{g}$ of protein).

\begin{tabular}{cc}
\hline Amino acid & T 8 \\
\hline Asp + Asn & 11.46 \\
Glu + Gln & 12.88 \\
Ser & 5.22 \\
His & 2.59 \\
Gly & 5.47 \\
Tre & 4.37 \\
Arg & 11.28 \\
Ala & 2.59 \\
Pro & 5.23 \\
Tyr & 32.79 \\
Val & 6.2 \\
Met & 1.06 \\
Cys & ND \\
Ile & 5.49 \\
Leu & 9.51 \\
Phe & 6.26 \\
Lys & 7.51 \\
\hline
\end{tabular}

ND: not detected.

of protein in GS may be mentioned by Sankalia et al. (2004) as explained in capsules formed with sodium alginate and calcium as a crosslinking agent, but molecules with high molecular weight and low solubility in water, retain their stability and no ability to swell in acidic media. The encapsulated material in this study was soluble in water and has a low molecular mass; these facts would be an explanation for the highest amount of protein released in the gastric system.

\subsection{ACE-I and antioxidant activity}

The values obtained for ACE activity in gastric and intestinal systems are shown in the Table 3 . Values shown are presented as $\mathrm{IC}_{50}$ which is the required amount of sample (in this case peptide fraction) for ACE activity is reduced by $50 \%$. The value in the intestinal system of all treatments was better in comparison to the non-encapsulated fraction $(0.37 \mathrm{mg} / \mathrm{mL}$ of $\mathrm{IC}_{50}$ ). Polanco-Lugo et al. (2014) reported values for ACE inhibition for extensive hydrolysates from $P$. lunatus with a value of $0.321 \mathrm{mg} / \mathrm{mL}$ of $\mathrm{IC}_{50}$. The values of treatments in IS were better than that reported by the above authors. Ruiz-Ruiz et al. (2013) reported $\mathrm{IC}_{50}$ values in gastric and intestinal environment for encapsulated $P$. lunatus hydrolysates, finding values ranging from 3.1 to $4.1 \mathrm{mg} / \mathrm{mL}$ for gastric system and values in a range 2.9 to $3.8 \mathrm{mg} / \mathrm{mL}$ for intestinal system; observed that the values obtained in this study also were better.

Kodera \& Nio (2006) reports the peptide sequence (Asp-Trp-Gly-Pro-Leu-Val) of soy protein shown an ACE-I activity. These amino acids were in a good amount in the IS of treatment 8 (Table 4). Calpis ${ }^{\circledR}$ and Evolus ${ }^{\circledR}$ reports a Val-ProPro and Ile-Pro-Pro peptides in functional milks (Hartmann \& Meisel, 2007) in this way the amount of Val, Pro, Ile and others amino acids could be responsible for ACE inhibition.

Antioxidant activity (TEAC) remnant of the peptide fraction in gastric and intestinal system is shown in Table 3.The remainder of the peptide fraction presented antioxidant activity is desirable as this may have a positive effect against free radicals and thus have a positive impact on oxidative stress. It has been observed that hydrolysates have the ability to decrease reactivity of free radicals (Elias et al., 2008). The TEAC value of treatment $8 \mathrm{in} \mathrm{mM} / \mathrm{mg}$ protein was of 100.76 , this value was higher than the reported by Torruco-Uco et al. (2009) for hydrolysate from $P$. lunatus obtained with the hydrolysis of Flavourzyme and Alcalase separately at different times with values in a range of 8.42 to $11.55 \mathrm{mM} / \mathrm{mg}$ protein.

Polanco-Lugo et al. (2014) reported the TEAC in extensive hydrolysate of $P$. lunatus with a value of $13.2 \mathrm{mM} / \mathrm{mg}$ protein, and this value was lowest in comparison to the obtained in this study. Amino acids like Tyr, Met, Trp, Leu, His and Lys were widely reported as having high antioxidant activity (Chen et al., 1998). This suggests the presence of these amino acids and the sequences between Tyr, Met, Trp, Leu, His and Lys in the protein of IS in treatment 8 may exhibit antioxidant activity. In the case of bioactivities it should be clear which one will be provided, for example, if a better antioxidant activity is desired then treatment 8 would be appropriate and this treatment would be providing an ACE-I $0.136 \mathrm{mg} / \mathrm{mL}$. On the contrary, if a higher ACE-I is desired, then the best treatments would be 2, 5 and 6 and in addition these treatments would bring a 673.10, 570.64 and $621.92 \mathrm{mM}$ of TEAC respectively. Although a good dosage of the peptidic fraction was not achieved, the combination of 
gums CFG:SA could be use in the encapsulation of cells or protein (not fractions) encapsulation but implementing another encapsulation technique, as mentioned by Yeo et al. (2001).

\section{Conclusion}

The gum blend of CFG/AS was not effective in the microencapsulation of peptide fractions of Phaseolus lunatus. However, it was observed that remnant bioactivity existed in both gastric and intestinal medium. Besides the combination of gums (CFG:SA) allowed a better encapsulation of peptide fractions compared with alginate alone.

\section{Acknowledgements}

This research was supported by the CONACYT through project 106605 and PROMEP-SEP.

\section{References}

Alaiz, M., Navarro, J. L., Girón, J., \& Vioque, E. (1992). Amino acid analysis by high-performance liquid chromatography after derivatization with diethyl ethoxymethylenemalonate. Journal of chromatography, 591(1-2), 181-186. http://dx.doi.org/10.1016/00219673(92)80236-N. PMid:1613051

Andreev, P. V. (2004). Drug synthesis methods and manufacturing technology using modified starch in the Russian pharmaceutical industry (A review). Pharmaceutical Chemistry Journal, 38(8), 447-450. http://dx.doi.org/10.1023/B:PHAC.0000048909.52734.82.

Association of Official Analytical Chemists - AOAC (1990). Methods of analysis of association of official analytical chemists (16th ed.). Washington: AOAC.

Bahamdan, A., \& Daly, W. (2006). Poly (oxyalkylene) grafts to guar gum with applications in hydraulic fracturing fluids. Polymers for Advanced Technologies, 17(9-10), 679-681. http://dx.doi. org/10.1002/pat.814.

Betancur-Ancona, D., Gallegos-Tintoré, S., \& Chel-Guerrero, L. (2004). Wet-fractionation of Phaseolus lunatus seeds: Partial characterization of starch and protein. Journal of the Science of Food and Agriculture, 84(10), 1193-1201. http://dx.doi.org/10.1002/ jsfa.1804.

Betancur-Ancona, D., Martínez-Rosado, R., Corona-Cruz, A., Castellanos-Ruelas, A., Jaramillo-Flores, M. E., \& Chel-Guerrero, L. (2009). Functional properties of hydrolysates from Phaseolus lunatus seeds. International Journal of Food Science \& Technology, 44(1), 128-137. http://dx.doi.org/10.1111/j.1365-2621.2007.01690.x.

Betancur-Ancona, D., Pacheco-Aguirre, J., Castellanos-Ruelas, A., \& Chel-Guerrero, L. (2011). Microencapsulation of papain using carboxymethylated flamboyant (Delonix regia) seed gum. Innovative Food Science \& Emerging Technologies, 12(1), 67-72. http://dx.doi. org/10.1016/j.ifset.2010.11.002.

Chau, C. F., Cheung, P. C. K., \& Wong, Y. S. (1997). Functional properties of protein concentrates from three Chinesse indigenous legume seeds. Journal of Agricultural and Food Chemistry, 45(7), 2500-2503. http://dx.doi.org/10.1021/jf970047c.

Chel-Guerrero, L., Domínguez-Magaña, M., Martínez-Ayala, A., Dávila-Ortiz, G., \& Betancur-Ancona, D. (2012). Lima bean (Phaseolus lunatus) protein hydrolysates with ACE-I inhibitory activity. Food and Nutrition Sciences, 3(4), 511-521. http://dx.doi. org/10.4236/fns.2012.34072.

Chel-Guerrero, L., Pérez-Flores, V., Betancur-Ancona, D., \& DávilaOrtiz, G. (2002). Functional properties of flours and protein isolates from Phaseolus lunatus and Canavalia ensiformis seeds. Journal of Agricultural and Food Chemistry, 50(3), 584-591. http://dx.doi. org/10.1021/jf010778j. PMid:11804533

Chen, H. M., Muramoto, K., Yamauchi, F., Fujimoto, K., \& Nokihara, K. (1998). Antioxidative properties of histidine-containing peptides designed from peptide fragments found in the digests of a soybean protein. Journal of Agricultural and Food Chemistry, 46(1), 49-53. http://dx.doi.org/10.1021/jf970649w. PMid:10554195

Cho, M. J., Unklesbay, N., Hsieh, F. H., \& Clarke, A. D. (2004). Hydrophobicity of bitter peptides from soy protein hydrolysates. Journal of Agricultural and Food Chemistry, 52(19), 5895-5901. http://dx.doi.org/10.1021/jf0495035. PMid:15366839

Elias, R. J., Kellerby, S. S., \& Decker, E. A. (2008). Antioxidant activity of proteins and peptides. Critical Reviews in Food Science and Nutrition, 48(5), 430-441. http://dx.doi.org/10.1080/10408390701425615. PMid:18464032

Hartmann, R., \& Meisel, H. (2007). Food-derived peptides with biological activity: from research to food applications. Current Opinion in Biotechnology, 18(2), 163-169. http://dx.doi. org/10.1016/j.copbio.2007.01.013. PMid:17292602

Hayakari, M., Kondo, Y. \& Izumi, H. (1978). A Rapid and Simple Espectrophotometric Assay of Angiotensin-Converting Enzyme. Analytical Biochemistry, 84, 361-369.

Iwaniak, A., \& Minkiewicz, P. (2007). Proteins as the source of physiologically and functionally active peptides. Acta Scientiarum Polonorum, Technologia Alimentaria, 6(3), 5-15.

Kapoor, V. P. (1972). A galactomannan from the seeds of Delonix regia. Phytochemistry, 11(3), 1129-1132. http://dx.doi.org/10.1016/ S0031-9422(00)88465-4.

Kodera, T., \& Nio, N. (2006). Identification of an angiotensin I-converting enzyme inhibitory peptides from protein hydrolysates by a soybean protease and the antihypertensive effects of hydrolysates in spontaneously hypertensive model rats. Journal of Food Science, 71(3), C164-C173. http://dx.doi.org/10.1111/j.1365-2621.2006. tb15612.x.

Lowry, O. H., Rosebrough, N. J., Farr, A. L., \& Randall, R. J. (1951). Protein measurement with the Folin phenol reagent. The Journal of Biological Chemistry, 193(1), 265-275. PMid:14907713.

Montgomery, D. C. (2001). Design and analysis of experiments (5th ed.). New York: John Wiley \& sons.

Nielsen, P. M., Petersen, D., \& Dambmann, C. (2001). Improved method for determining food protein degree of hydrolysis. Journal of Food Science, 66(5), 642-646. http://dx.doi.org/10.1111/j.1365-2621.2001. tb04614.x.

Pacheco-Aguirre, J., Rosado-Rubio, G., Betancur-Ancona, D., \& Chel-Guerrero, L. (2010). Physicochemical properties of carboxymethylated flamboyant (Delonix regia) seed gum. CyTA - Journal of Food, 8(3), 169-176. http://dx.doi. org/10.1080/19476330903322960.

Polanco-Lugo, E., Dávila-Ortiz, G., Betancur-Ancona, D. A., \& ChelGuerrero, L. A. (2014). Effects of sequential enzymatic hydrolysis on structural, bioactive and functional properties of Phaseolus lunatus protein isolate. Food Science and Technology (Campinas). Retrieved from http://www.scielo.br/scielo.php?script=sci_ abstract\&pid=S0101-20612014005000026\&lng=en\&nrm=iso\&t $\operatorname{lng}=$ en

Pukalskas, A., van Beek, T. A., Venskutonis, R. P., Linssen, J. P., van Veldhuizen, A., \& de Groot, A. (2002). Identification of radical scavengers in sweet grass (Hierochloe odorata). Journal of 
Agricultural and Food Chemistry, 50(10), 2914-2919. http://dx.doi. org/10.1021/jf011016r. PMid:11982419

Rodrigues, E., Poerner, N., Rockenbach, I. I., Gonzaga, L. V., Mendes, C. R., \& Fett, R. (2011). Phenolic compounds and antioxidant activity of blueberry cultivars grown in Brazil. Ciência e Tecnologia de Alimentos, 31(4), 911-917.

Ruiz-Ruiz, J., Segura-Campos, M. R., Betancur-Ancona, D. A., \& ChelGuerrero, L. (2013). Encapsulation of Phaseolus lunatus protein hydrolysate with Angiotensin-Converting Enzyme Inhibitory Activity. ISRN Biotechnology, 2013, 1-6. Retrieved from http://www. hindawi.com/isrn/biotechnology/2013/341974/

Sankalia, M. G., Mashru, R. C., Sankalia, J. M., \& Sutariya, V. B. (2004). Evaluación y optimización simultánea de papaína inmovilizada en gránulos de alginato entrecruzado mediante un diseño factorial $3 \mathrm{x}$ 3 y la función de deseabilidad. Ars Pharmaceutica, 45(3), 253-279.

Segura-Campos, M., Chel-Guerrero, L., Betancur-Ancona, D., \& Hernández-Escalante, V. (2011). Bioavility of bioactive peptides. Food Reviews International, 27(3), 213-226. http://dx.doi.org/10.1 080/87559129.2011.563395.

Schägger, H., \& Von Jagow, G. (1987). Tricine-sodium dodecyl sulfate-polyacrylamide gel electrophoresis for the separation of proteins in the range from 1 to $100 \mathrm{kDa}$. Analytical Biochemistry, 166(2), 368-379. http://dx.doi.org/10.1016/0003-2697(87)90587-2. PMid:2449095

Sica, D. A. (2007). Combination ACE inhibitor and angiotensin receptor blocker therapy - future considerations. Journal of Clinical Hypertension, 9(1), 78-86. http://dx.doi.org/10.1111/j.15246175.2007.6359.x. PMid:17215664

Swarbrick, J. (1997). Encyclopedia of pharmaceutical Technology. New York: Marcel dekker.

Takagi, K., Teshima, R., Okunuki, H., \& Sawada, J. (2003). Comparative study of in vitro digestibility of food proteins and effect of preheating on the digestion. Biological \& Pharmaceutical Bulletin, 26(7), 969973. http://dx.doi.org/10.1248/bpb.26.969. PMid:12843620
Tamaki, Y., Teruya, T., \& Tako, M. (2010). The chemical structure of galactomannan isolated from seeds of Delonix regia. Bioscience, Biotechnology, and Biochemistry, 74(5), 1110-1112. http://dx.doi. org/10.1271/bbb.90935. PMid:20460705

Torruco-Uco, J., Chel-Guerrero, L., Martínez-Ayala, A., Dávila-Ortíz, G., \& Betancur-Ancona, D. (2009). Angiotensin-I converting enzyme inhibitory and antioxidant activities of protein hydrolysates from Phaseolus lunatus and Phaseolus vulgaris seeds. Food Science and Technology, 42, 1597-1604.

Vioque, J., Pedroche, J., Yust, M. M., Lqari, H., Megías, C., Girón-Calle, J., Alaiz, M., \& Millán, F. (2006). Bioactive peptides in storage plants proteins. Brazilian Journal of Food Technology, III JIPCA, 99-102.

Yeo, Y., Baek, N., \& Park, K. (2001). Microencapsulation methods for delivery of protein drugs. Biotechnology and Bioprocess Engineering; BBE, 6(4), 213-230. http://dx.doi.org/10.1007/BF02931982.

Yust, M. M., Pedroche, J., Girón-Calle, M. A., Millán, F., \& Vioque, J. (2003). Production of ACE inhibitory peptides by digestión of chickpea legumin with alcalase. Food Chemistry, 81(3), 363-369. http://dx.doi.org/10.1016/S0308-8146(02)00431-4.

Yust, M. M., Pedroche, J., Girón-Calle, J., Vioque, J., Millán, F., \& Alaiz, M. (2004). Determination of tryptophan by highperformance liquid chromatography of alkaline hydrolysates with spectrophotometric detection. Food Chemistry, 85(2), 317-320. http://dx.doi.org/10.1016/j.foodchem.2003.07.026.

Xu, X., Yao, S., Han, N., \& Shao, B. (2007). Measurement and influence factors of the flowability of microcapsules with high-content $\beta$-carotene. Chinese Journal of Chemical Engineering, 15(4), 579-585. http://dx.doi.org/10.1016/S1004-9541(07)60127-X.

Zhao, H., Cheng, F., Li, G., \& Zhang, J. (2003). Optimization of a process for carboxymethyl cellulose (CMC) preparation in mixed solvents. International Journal of Polymeric Materials, 52(9), 749-759. http:// dx.doi.org/10.1080/713743713. 